\title{
THE INTRODUCTION OF BIOTERRORISM IN MALAYSIA: A LEGAL APPROACH
}

\author{
Nor Anita binti Abdullah ${ }^{1}$ \& \\ Rohani binti Abdul Rahim²
}

\begin{abstract}
The deliberate use of biological agents and the emergence of infectious diseases which can produce harm to human health and give effects to the public health and security are well recognised. A few years back, an attack of biological agents would be the most unthinkable situation to happen. However, the threat of bioterrorism is real and it is growing. It continues to be a major challenge today and the possibility of bioterrorism is undeniable as it is increasingly defined globally as 'not if, but when'. Therefore, this paper attempts to give a brief explanation on the threat of bioterrorism as to the emergence of infectious diseases and the legal history of international law on bioterrorism. The main objective of this paper is to find out the need for bioterrorism law in Malaysian i.e. a legal approach. The study is a social legal research, which uses a qualitative approach. Thus, due to lack of materials and publications in Malaysia, in order to achieve the objectives, the methodology used was based on a semi structured interviews conducted with three respected experts in public health and security to explore the real situation in Malaysia. The authors found out that the finding of this study had established that an outbreak of infectious diseases can now be viewed as a threat that may result to bioterrorism if there is no preparation to handle it.
\end{abstract}

Keywords: Bioterrorism, biological agents, infectious diseases, legal and preparedness

\section{Introduction}

Bioterrorism started for centuries ago since biological agents have been used either for weapon purposes or criminal activities. Based

1 College of Law, Government and International Studies (COLGIS), Universiti Utara Malaysia, 06010, Sintok, Kedah, E-mail: noranita abdullah@yahoo.com / noranita@uum.edu.my

2 Faculty of Law, Universiti Kebangsaan Malaysia, 43650 Bandar Baru Bangi, Selangor. E-mail: rohani rahim@yahoo.co.uk / rar@ukm.my 
on the historical perspectives, there have been a few instances to confirm in which a terrorist has used it to start warfare. There are many reasons why biological and toxin weapons are likely to become very interesting agent especially to the criminals and terrorist in the $21^{\text {st }}$ century. The reason is due to the growth of biotechnology, pharmaceutical, environmental and health care industries where a lot of people become experts in microbiology and any related biosciences. The advancement of the new technology has increased where more people have access to expert in advance technology. Most of these new technologies can be used for the manufacturing of biological weapons. In fact, the new technologies related to biological weapons are emerging rapidly. Furthermore, the information on how to produce the agents is easily accessible. It is undoubtedly creating a greater threat with severe implications to the public at large. Through the agents and diseases, it will be designed to produce for new types of weapon. This scenario is not a mere fiction anymore. In fact, this is what we have to face in reality and it is possible due to the impact of biotechnology and also the production of the biological weapons from the use of the agents and diseases.

The fact that a biological attack has occurred would therefore not become known until sometime later due to some reason where it may be misdiagnosed in the first place. It has occurred and no doubt that it could occur again at any time with no expectation under any circumstances. There was a report made on the news of bioterrorism in the British Medical Association (BMA) where it stated that 'bioweapons that target selected ethnic groups could become a part of the terrorists' arsenal...', and 'the threat from bioweapons has outstripped that from chemical and nuclear arms because of the riotous progress of biotechnology'. ${ }^{3}$ This statement stressed on the emergence of biological use as a threat due to the advancement of modern technologies nowadays.

\section{Objectives and Methodology}

Undoubtedly that bioterrorism raises questions of security and public health as well as legal significance in handling, managing, solving and preventing the problem. What lesson can be learnt

3 Zalini Yunus, "Combating and Reducing the Risk of Biological Threats," The Journal of Defence and Security 1, no. 1(2010): 1 
from what had happened from the events of 11 September, 2001? How to arrive at an accurate picture to understand the threat and the spread of bioterrorism? What can and should be done to deal with these threats? Who should bear the responsibility? How to react? How law can be used as tools to prevent the emergence of bioterrorism? Which system is the best to be used to ensure the public's safety and health? Why would anyone use disease to cause death of others? These are the questions to be raised if bioterrorism threats become a reality and in fact, there are a lot of questions yet to arise. The threat is not only real, it is also growing in line with the world development due to advancement in biological sciences and technologies. Bioterrorism represents a great breakthrough to the public as to their response in understanding the risks and the most important part is how they act to reaction appropriately towards the event of bioterrorism whenever it occurs..

Therefore, this paper attempts to study about the threat of bioterrorism and the emergence of infectious diseases that can cause bioterrorism if there is no further action taken. In order to complete this paper, the authors will enlighten the legal history of international law on bioterrorism to widen the understanding and knowledge on the emergence of bioterrorism to this world. By looking into Malaysian perspective, terrorism is well known among the public as compared to bioterrorism. Perhaps it is vital to highlight that, terrorism is specifically mentioned under Malaysian provisions such as provided under Penal Code, Internal Security Act 1960 (repealed in 2011). Thus, this paper will look into the existence of terrorism under Malaysian law by looking into the need for bioterrorism law in particular.

In order to achieve the objectives of this paper, the authors adopted a socio legal study using a qualitative approach. Legal research alone is insufficient to obtain solution involving social issues pertaining to public health and security matter. In fact, there is no such event of bioterrorism yet to occur in Malaysia. Thus, due to lack of written materials and information in Malaysia, the authors conducted a semi structured interviews with three experts chosen from the relevant field of public health and security. The experts were from Science and Technology Research Institute for Defense (STRIDE) under the Ministry of Defence, Veterinary Services Department and Tropical Infectious Disease Research and Education Center (TIDREC). The 
authors provided a semi structured questions and three experts were assigned with a different set of questions which actually varied on every one of them in particular to their respected expertise. The purpose of assigning a different set of question was to obtain only a related data as needed especially on their expertise and knowledge in their own area and the organization in which they are representing. ${ }^{4}$ The data collected from the interviews happened to be the most appropriate and helpful source of information in the completion of the writing of this paper. Malaysia had no experience in dealing with and managing the threats of bioterrorism, thus interview session were particularly useful for getting the real fact and information needed in which the authors can pursue in-depth all information about bioterrorism and any issue which is related to the subject. ${ }^{5}$

\section{Introduction of Bioterrorism}

Model State Emergency Health Power Act 2001 (Model Act) defines bioterrorism as:

'...the intentional use of any microorganism, virus, infectious substance or biological product that may be engineered as a result of biotechnology, or any naturally occurring or bioengineered component of any such microorganism, virus, infectious substance, or biological product, to cause death, disease, or other biological malfunction in a human, an animal, a plant, or other living organism in order to influence the conduct of government or to intimidate or coerce a civilian population...'.

Bioterrorism is categorised as a new form of terrorism. Nowadays, weapons are no longer needed to cause war to create terrorism. ${ }^{6}$

4 Chua Yan Piew, Kaedah Penyelidikan (Kuala Lumpur: Mc Graw Hill Education, 2006), 116-117. See also Rohana Yusof, Penyelidikan Sains Sosial (Kuala Lumpur: PTS Publications, 2004), 35-37.

5 Micheal Quinn Patton, Qualitatitve Evaluation and Research Methods $2^{\text {nd }}$ Ed (London: Sage Publications, 1990), 12-13.

6 Nor Anita Abdullah and Rohani Abdul Rahim, "Bioterrorism: New Threats to Health and Security." (paper presented at the international seminar and workshop on terrorism, Terrorism: Redefining, Preventing and Combating, Faculty of Laws, University Brawijaya, Malang, East Java, Indonesia, June, 24-25, 2011). 
Medical prospect turns to be effective mechanisms to achieve their goal to destroy and cause harm among people. ${ }^{7}$ Bioterrorism is defined as an intentional release of biological agents (bacteria, viruses, or other germs) to the public. The deliberate use of those agents is to cause disease, death, fear and panic. The threat from the biological agents may arise naturally when people make use of it and modify it to increase virulence to the public either by causing diseases or killing people. Thus, the availability of these agents is potentially to be used and exploited as biological weapon to create bioterrorism. The possibility of using biotechnology may have application to produce biological weapons through biological agents.

In order to understand the aspects of bioterrorism, it is important to be on familiar terms with the classification of agents. Center for Disease Control and Prevention (CDC) has divided the agents which can be used as biological weapons into three categories. ${ }^{8}$ The categories depends on the potential effects of the agents and how easily the agent can spread from person to another person, what length it can cause illness and death to the person infected and the potential of each agents to cause public panic, fear and social disruption.

\section{Table 1}

Classification of agents which can be used as biological weapo

\begin{tabular}{llll}
\hline Category & \multicolumn{1}{c}{ Characteristics } & \multicolumn{1}{c}{ Agents/Diseases } \\
\hline A & High priority agents include & - & Anthrax (Bacillus anthracis), \\
& organism that pose a risk to \\
national security because they: & - & Botulism (Clostridium \\
& botulinum toxin), \\
& $-\quad$ Can be easily disseminated & - & Plague (Yersinia pestis), \\
& or transmitted from person to & - & Smallpox (variola major), \\
& person; & - & Tularemia (Francisella \\
& Result in high mortality rates & & tularensis), \\
& $\begin{array}{l}\text { and have the potential for } \\
\text { major public health impact; }\end{array}$ & \\
&
\end{tabular}

7 Albert Robida expressed his view in Le Vingtime Siecle (The Twentieth Century) that ' ... the times to be favorable for making medical war! ...More than explosives as in former times, but only the artillery of outrescence, microbes of bacilli sent into the territory of enemy...'.

8 Centers for Disease, Control and Prevention Portal at http://www.bt.cdc.gov/ agent/agentlist.asp (accessed September 13, 2012) 
- Might cause public panic and Viral hemorrhagic fevers social health disruption; and (filoviruses [e.g., Ebola, - Require special action for Marburg] and arenaviruses public health preparedness. [e.g., Lassa, Machupo])

B

Second highest priority agents include those that:

- Brucellosis (Brucella

- Are moderately easy to disseminate species)

Result in moderate morbidity

- Espilon toxin of Clostridium perfringens rates and low mortality rates; Food safety threats (e.g and

Salmonella species,

Require specific Escherichia coli 0157:H7, enhancements of available diagnostic capacity and enhanced disease surveillance. Shigella)

- Glanders (Burkholderia mallei)

- Melioidosis (Burkholderia pseudomallei)

- Psittacosis (Chlamydia psittaci)

- Q fever (Coxiella burnetti)

- Ricin toxin from Ricinus communis (castor beans)

- Staphy lococcal enterotoxin B

- Typhus fever (Rickettesia prowazekii)

- Viral encephalitis (alpha viruses [e.g Venezuelan equine encephalitis, eastern equine encephalitis, western equine encephalitis])

- Water safety threats (e.g Vibrio cholera, Cryptosporidium parvum)

C Third highest priority agents include emerging pathogens that

- Emerging infectious disease such as Nipah virus and could be emerging pathogens hantavirus.

that could be engineered for mass dissemination in the future because of

- Availability

- $\quad$ Ease of production and dissemination; and

- $\quad$ Potential for high morbidity and mortality rates and major health impact. 
According to Table 1, Category A agents are considered the highest priority agents which caused the highest and greatest bioterrorism risk among the other categories. The diseases from the Category A are fairly easily disseminate to the public and also resulted to greater public health impact and pose a threat to national security. While for Category B, the agents also known as the second highest priority agents because the spread from this category is quite moderate as compared to Category B, but still causing public health impact with moderate rates. The last one is the agents from Category $\mathrm{C}$ as a third priority agent which bring into being the lowest risk, ${ }^{9}$ but it can be engineered and turn out to cause greater harm to public health by anyone who had an intention to misuse the easy availability of the agents. ${ }^{10}$ Furthermore, creativity and innovation are becoming increasingly important for the world development today. Thus, by looking into the development in the modern and sophisticated technology which in line with the people's creativity today, it provides an overview that people can do anything without boundaries. The risk is everywhere and anywhere.

In relation to the comprehensive and well developed technology, most of the biological agent's production will affect the human life. However, it is extremely difficult to detect and do not cause illness from the first day it was used until a few days later. Thus, it is important to know the existence of a few potential instances and uncertainties inherent in a biological attack:

i. A biological weapon attack is not easy to detect until victim begin to show the symptoms;

ii. Although the symptom shown, additional time is needed to identify the causative agents;

iii. It is difficult to determine the exact areas detected and the number of person exposed, to identify those exposed and to determine the necessary conduct to deal with;

9 Yunus, n. 3 at 5.

10 Malcolm R. Dando and Kathryn Nixdorff, "An Introduction to Biological Weapons," in BWPP Biological Weapons Readers, ed. Kathryn McLaughlin and Kathryn Nixdorff (Geneva, 2009),8 http://www.bwpp.org/documents/ BWPP\%20BW\%20Reader_final+.pdf (accessed August 29, 2012). See also article of "Biological and Chemical Agents", pp. 25-26 at http://www.who.int/ csr/delibepidemics/chapter3.pdf (accessed September 10, 2012). 
iv. It is difficult to vaccinate the target population (normally no vaccine is available for most of the agents);

v. Treatments options are limited and maybe not exist at all;

vi. The public health system are not well equipped to accommodate the widespread of infectious diseases caused by the biological attack; and

vii. The attack will cause fear and panic to the public at large. ${ }^{11}$

\section{International Law on the Emergence of Bioterrorism}

The first law used to control bioterrorism begun in 1899 known as Hague Convention. The first prohibition of the use of biological agents was stated clearly in Article 23 of the Hague Convention which states that 'besides the prohibitions provided by special Conventions, it is especially prohibited (a) to employ poison or poisoned arms. However, the Hague Convention 1899 was not the only convention forced on the prohibition of the use of biological agents. The latest Hague Convention which was introduced in 1970 had also aggressively opposed the use of biological agents. However, the law which discussed the issue on the prohibition of the use of biological agents before the introduction of Hague Convention was introduced as early as 1921 known as the Geneva Protocol 1921. In the meantime, the Geneva Protocol was amended and finally, in 1925 the Geneva Protocol for the Prohibition of the Use in War or Asphyxiating Poisonous or Other Gases, and of Bacteriological Methods of Warfare (Geneva Protocol 1925) had included 'bacteriological' warfare with chemical prohibitions.

Originally, the Geneva Protocol of 1925 only banned the chemical use of weapon in war but later it was extended to include biological weapon. Thus, throughout the history of law, the existence of biological warfare is known from the earliest time. However, the development of the law was not developed until recent day when people have a propensity to misuse the biological agents as weapon. ${ }^{12}$

11 Ken Alibek and Catherine Lobanove, "Modulation of Innate Immunity to Protect Against Biological Weapon Threats," in Microorganisms and Bioterrorism, ed. Burt Anderson, Herman Friedman and Mauro Bendinelli, (USA: Springer, 2006), 57.

12 Victoria Sutton, Law and bioterrorism (USA: Carolina Academic Press, 2003), 3-7. 
Thus, as a result, the Geneva Protocol 1925 addressed the prohibition of the use of biological agent as weapons. This protocol clearly stressed that the use of poison chemical (toxic) and diseases in war would be illegal according to international provisions. ${ }^{13}$ Later, reinterpretation has been made to the Geneva Protocol 1925 in 1969 in Nations General Assembly which resulted to the introduction of the Convention on the Prohibition of the Development, Production and Stockpiling of Bacteriological (Biological) and Toxin Weapons and on their Destruction (also known as Biological Weapons Convention $1972(\mathrm{BWC})){ }^{14}$

BWC acts as a first multilateral disarmament of international and legal treaty banning the production of the entire category of weapons. ${ }^{15}$ Unfortunately, there were a few weaknesses and loophole in BWC. It did not describe clearly the verification to comply with the terms in BWC itself. ${ }^{16}$ Among the weaknesses of BWC is, it clearly stressed the provision to prohibit the use of biological agent as weapons but no restriction provided especially for 'dual-use' purpose. ${ }^{17}$ Under this condition, it is not surprising enough to see many countries violated the provisions in the first place. Most of the

13 Scott Spence and Ralf Trapp, "A Brief Comparison on Chemical and Biological Weapons Conventions," in BWPP Biological Weapons Reader, ed. Kathryn McLaughlin and Kathryn Nixdorff (Geneva, 2009), 45. http://www.bwpp.org/ documents/BWPP\%20BW\%20Reader_final+.pdf (accessed August 29, 2012).

14 Spence and Trapp, "A Brief Comparison on Chemical and Biological Weapons Conventions," 44.

15 BWC was opened for signature in 10 April 1972 and signed in London, Washington and Moscow. It was enforced in 26 March 1975 after four steps of re-evaluations through the conferences in 1980, 1986, 1991 and 1996. It has been ratified by 140 countries worldwide in May, 1997. The BWC also gave impetus to the negotiation of a Chemical Weapons Convention in Article IX states 'Each State Party to this Convention affirms the recognized objective of effective prohibition of chemical weapons and, to this end, undertakes to continue negotiations in good faith with a view to reaching early agreement on effective measures for the prohibition of their development, production and stockpiling and for their destruction, and on appropriate measures concerning equipment and means of delivery specifically designed for the production or use of chemical agents for weapons purposes'.

16 Maurice R. Hilman, "Overview: cause and prevention in biowarfare and bioterrorism." Vaccine 20, (2002): 3055.

17 "Bio-terrorism." Postnote of Parliamentary Office of Science and Technology, No. 166, (2006): 4. 
countries have their own research facilities and programmes. They particularly conduct a research by using the biological agents and existence of infectious diseases for research purposes. Their findings and result on the research will always be questionable whether it is for the benefit of mankind or vice versa. It is difficult to determine the status of the research itself because of dual-use purpose. In fact, some of the countries have developed their own biological weapons programmes. Unfortunately, there was no evidence to point them in violation of the BWC. Therefore, all efforts have been done to verify the mechanisms and it was considered as a challenge to BWC until today. ${ }^{18}$

\section{The Emergence of Infectious Diseases: As Weapon}

The historical lesson cautions us about the dangers of bioterrorism to be taken into consideration. The pandemic outbreak has been used as weapon for a long time ago in starting bioterrorism in the first place. There was a long history since people using biological agents as weapon. During the period, it was difficult to determine the existence of infectious diseases was due to the deliberate release of biological agent as weapon or confounded by other naturally occurring factors such as the emergence of infectious diseases naturally. The most references throughout the history using biological weapon in Kaffa in 1346 which involved an outbreak of plague. Another example was the use of smallpox as weapon during the French and Indian war in 1763. During the World War 1, there was a report claiming that Germans used plague against Russian in 1915 and attempted to use cholera against Italy. ${ }^{19}$ Another history was the use of Brucella as an agent of biological warfare to cause bioterrorism in World War II due to its highly infectious. Bioterrorist would prefer to use Brucella because it is useful as agent for biological warfare and produced a long term effect and risks. It may take weeks before the exposure is detected. Once detected, there is no effective vaccine available in short time period in order to cure the effects of this infectious disease. ${ }^{20}$

18 Yunus, no. 3at 8-9.

19 Rebecca Katz, "Biological Weapons: a National Security Problem That Requires a Public Health Response.” (paper presented at the Working Paper Series 20012004, Office of Population Research of Princeton University (2001-2004): 6.

20 Michelle Wright Valderas \& R. Martin Roop II, "Brucella and Bioterrorism," in Microorganisms and Bioterrorism, ed. Burt Anderson, Herman Friedman and Mauro Bendinelli (USA: Springer, 2006), 143. 
Bioterrorism was unforeseen in the first place. The consequences exist from the biological weapons would be unimaginable. The event of September, 11 had killed five people and infected at least thirteen postal servants from the attack of anthrax. Most of them inhaled the spores contained in the letters sent through the U.S Postal Service. ${ }^{21}$ Until now, no one has been charged and held responsible for the act. It is undeniable to say that the emergence of infectious diseases had caused major threat to the public health as well as security system. It is proven that during the World War 1, disease had killed more soldiers than battle injuries where about 85 per cent of hospital admissions were for treatment of disease and only about 3 per cent for battle injuries. ${ }^{22}$

Furthermore, the World Health Organization (WHO) outlined that the emergence of infectious diseases represent a global threat that will require a coordinated and global response. The threat is considered as global because the nature of the diseases itself to emerge anywhere and everywhere in the planet, widespread to other regions. ${ }^{23}$ As stated earlier, the spread of the infectious diseases will involve microbes and viruses which ignore geographical boundaries and also involves cross border issue. The nature of the disease it caused among human being regardless of whether or not the infection is acquired naturally or being infected as a result of intentional exposure, both are potentially considered as a threat to be used as an agent for bioterrorism.

\section{Malaysian Overview and Legal Protection}

\section{Malaysian Experiences in Handling and Managing Emerging Biological Threats}

Malaysian past experiences had shown that there was no event of bioterrorism in the sense of intentional release of biological agents as

21 The postal workers' reluctant to receive the vaccine may have due in part to the distrust and resentment that had developed over the previous months as government official focused their treatment resources by mistakenly believing that anthrax could not be transmitted through unopened envelopes.

22 Anabelle Duncan, "A history of biological weapons black death \& yellow rain." Biological Weapons Convention Regional Workshop, ed. R J Mathews, Asia Pacific Centre for Military Law. Melbourne University Law School (2005): 23.

23 DavidP.Fidler,"Globalization,InternationalLaw, andEmergingInfectious Diseases," Perspectives of Emerging Infectious Diseases 2, no. 2 (April-June 1996): 77. 
an act of terrorism i.e., by looking at what happened in 11 September, 2001 or by virtue of the history which has evolved over the centuries in the World War I and World War II. There were no cases reported which resulted to the existence of the use of biological agents as weapon which can create the event of bioterrorism. However, Malaysia had its own experience in handling emerging biological threat through the emergence of infectious diseases such as the very famous Severe Acute Respiratory System (SARS) in 2003 and Nipah Virus in 1998. The phenomena have revealed how Malaysia handled and managed the threat in the very effective trial through the help from international collaboration. In facing the situation, Malaysia chose not to act in isolation.

Thus, collaborations with WHO and IHR were taken into account as guidelines to be implemented in any event of an outbreak. Malaysia also had responded to the Global Alert which has been issued by WHO as first precautionary enforcement towards the attack of any infectious diseases worldwide. In 1998, the attack of Nipah virus as the mysterious outbreak in the peninsular region of Malaysia had caught public health officials by surprise. Prior the attack, Malaysia had no experience at all in handling and managing the outbreak of the disease. It caused widespread panic and fear among the public. With the help from the collaboration of international organizations, Malaysia learnt much lesson theoretically and practically on how to manage the situations. That was a process of learning and Malaysia took it as a lesson in providing for a better preparedness alert in the event of bioterrorism, if it arises at anytime, anywhere and everywhere.

Based on the unpredictable event of bioterrorism as mentioned before, a statement pointed out by the Veterinary Officer, ${ }^{24}$ on which she stressed that most of the viruses are originated from animals (zoonosis). Thus, the infectious diseases which inflicted from the animal can easily be transmitted from animals to human or from human to animals. She gave an example of the emergence of Nipah Virus in 1998 and the outbreak resulted from person to person transmission which started from the sick pigs. In fact, Nipah Virus

24 Interview with Dr. Zurin Azlin, Veterinary Officer at Department of Veterinary Services Perak on 28 February 2011. 
has a potential as an agent for bioterrorism ${ }^{25}$ (Category $\mathrm{C}$ in the List of Agents as mentioned before). This situation leads to draw an attention to the public not to close their eyes to any possibility of the event of bioterrorism.

She further added that, the veterinary department also implemented normal procedures of prevention, control and preparation to prevent any transmission of the diseases from animals to person and to another person. Each implementation is different depending on the type of infectious diseases and the type of animal carriers of infectious disease. Procedures or protocols implemented are varying depending on the type of infectious disease and animals. For example, the process of 'stamping out' is taken to kill the animal in the identified areas of infectious disease around one kilometer. In the locality of two to ten kilometers, another process of surveillance or monitoring will be conducted by the veterinary department. At this stage, samples from the animals will be taken. If the result of the test is positive, the animals will be killed to avoid further transmission. This procedure is carried out on zoonotic infectious diseases such as HPA1, Japanese Encephalitis (JE) and Nipah virus. The process continues until the infected area is declared free. In particular, the veterinary department has a conjunction and collaboration with farmers to ensure the effectiveness of the actions taken. Their cooperation turns to be the most effective method to implement prevention, control and preparation planned by the veterinary department.

According to the Veterinary Officer also, there is another process known as quarantine. To provide the service, the Department of Veterinary Service has been authorized for quarantine procedures on animals or birds whenever necessary. Failure to comply with the requirements may result in confiscation of such animals and consequently, the importer may be charged for penalties for the wrongdoings. Most of the infectious diseases are caused by zoonotic. Thus, quarantine is the best method applied to prevent and control the spread of diseases. Animal tested with contagious disease needs to be quarantined especially imported animals. The main purpose of the quarantine procedures carried out by the Department of Veterinary

25 Lam Sai Kit, "Nipah Virus - A Potential Agent for Bioterrorism," Antiviral Research 57, (2003): 113. 
Service is for the purpose of communicable disease control and for the export and import of animals. In fact, the quarantine process was established in the occurrence of infectious diseases in Perak due to Nipah virus attacks. ${ }^{26}$ Thus, on the initiation of strict quarantine procedures, adherence to appropriate biosecurity and quarantine procedures within facilities, as with other contagious diseases, is of paramount importance in preventing spread of the infection from other countries into our Malaysian country and vice versa.

There are also cooperation with other government bodies such as Perhilitan, the Customs Department, Ministry of Home Affairs, Ministry of Consumer and Ministry of Health (MOH). Veterinary Department actually acts as a body of authority in preventing, controlling and preparing for any kind of possible threats of infectious diseases. To deal with the future unpredictable event, the help and collaboration with the international organisation at the international level had helped Malaysia learnt throughout the experiences to cope with the event whenever it occurs in the future. Thus, Malaysia was more than ready during the outbreak of SARS. For example, there was a professional collaboration between all parties. Furthermore, preparation of reference materials and guidelines on SARS on the clinical management on SARS were taken as an early warning for any detection and response to the outbreak. The public was made to know about the outbreak. The information of the event was disclosed in order to avoid any unexpected circumstances among the public or to rely on any rumors from unexpected sources. ${ }^{27} \mathrm{~A}$ precautionary measure was taken by Malaysia as advised by $\mathrm{MOH}$ in handling and managing the disease spread. Any enquires of the latest information and facts from the public was handled professionally especially by $\mathrm{MOH}$ in order to avoid any discrepancies later.

Throughout the past experiences, Malaysia has not only been supported by WHO-IHR but support also came from the World Organization for Animal Health (OIE) and Food and Agriculture

26 Interview with Dr. Zurin Azlin, Veterinary Officer at Department of Veterinary Service Perak on 28 February 2011.

27 Rohani Abdul Rahim and Nor Anita Abdullah, "SARS Threats on Public Health in Malaysia: Issues and Challenges." (paper presented at the international conference on Corporate Law 2009: Contemporary Roles and Challenges, Airlangga, Surabaya, June, 3-4, 2009). 
Organization (FAO) to strengthen international surveillance and detection of infectious diseases affecting human, plants and animals. The OIE works to make sure national Veterinary Services throughout the world are effective in preventing and controlling animal diseases. ${ }^{28}$

In addition, Tropical Infectious Diseases Research Center and Education (TIDREC) was established in collaboration with WHO as a research center to identify the emergence of infectious disease and discovers a method of treatment and vaccine to any potential threats of infectious diseases in Malaysia. TIDREC acts as a conjunction between the security agencies such as STRIDE and Ministry of Defence throughout the research on the misuse of biological agents or infectious disease as a biological weapon for the purpose of starting disruptive in Malaysia. According to the Director of TIDREC, ${ }^{29}$ based on Malaysian experiences in handling and managing H1N1 and SARS, it is vital to note that a research needs to be conducted on how to improve the level of prevention and preparedness in public health and security. Before this, the samples of infectious diseases acquired should be sent to CDC due to lack of ability and facilities to conduct a research. However, with the establishment of TIDREC, it helps the Malaysian researchers and scientists to conduct a research without being overly dependent to CDC anymore.

The cooperation among these organizations could also be considered as a contribution of BWC's objective as Malaysia is one of the StateMember. ${ }^{30}$ Although, in reality, there is no phenomenon that Malaysia does produce its own biological weapons. However, Malaysia had joined the BWC to support the efforts by the international community at the international level and to observe the provisions in handling and managing the infectious diseases which has potential to be used as an agent for bioterrorism. Malaysia maintains its assurance that the BWC is essential for the maintenance of international and

28 Interview with Dr. Zurin Azlin, Veterinary Officer at Department of Veterinary Service Perak on 28 February 2011.

29 Interview with Prof. Dr. Sazaly Abu Baker, Director of Tropical Infectious Diseases Research Center and Education (TIDREC) on 18 January 2012.

30 Zalini Yunus, Wong Mee Choo and Devan K. Ramu "Experiences of Malaysia in Implementing the Biological Weapons Convention.” Biological Weapons Convention Regional Workshop, edited by R J Mathews, Asia Pacific Centre for Military Law. Melbourne University Law School (2005):117-118. 
regional peace and security. In that sense, Malaysia is committed to undertake all possible efforts to fulfill its obligations under the BWC. $^{31}$

According to Science and Technology Research Institute for Defense (STRIDE) under the Ministry of Defence, efforts have been done to ensure the implementation of BWC. ${ }^{32}$ In line with the implementation of BWC, Malaysia had enacted its own Act known as Chemical Convention Act 2005. This Act actually covers the prohibition of the use of chemical as prohibited item and also as chemical weapon. Currently, there is no specific Act pertaining to the prohibition of the use of biological weapon in Malaysia. However, to show that Malaysia has an effort to comply with the implementation as provided under BWC, the Malaysian Draft of Biological Weapon and Toxin Convention is currently debated in order to undertake the obligation of BWC specifically.

\section{Protection and Measures: Legal Provisions}

Malaysian Federal-state relations are governed by Part VI of the Federal Constitution. There are three lists, the Federal List, the State List and the Concurrent List, listed in the Ninth Schedule. ${ }^{33}$ The Federal List sets out those subjects on which only Parliament can legislate. While the State List sets out those subject on which only the State Legislative Assemblies can legislate and the Concurrent List sets out the subjects on which either Federal or State may

31 Article IV of the BWC requires States Party, in accordance with their constitutional processes, to "...take any necessary measures to prohibit and prevent the development, production, stockpiling, acquisition or retention of the agents, toxins, weapons, equipment and means of delivery specified in Article I of the Convention, within the territory of such State, under its jurisdiction or under its control anywhere"

32 Interview with Dr. Zalini Yunus, Head of Human Factors, Protection and Biophysical Technology Division, Science and Technology Research Institute for Defence (STRIDE), Ministry of Defence, on 27 December 2011.

33 See Article 74 clause (1) of the Malaysian Federal Constitution, which states that 'Without prejudice to any power to make laws conferred on it by any other Article, Parliament may make laws with respect to any of the matters enumerated in the Federal List or the Concurrent List (that is to say, the First or Third List set out in the Ninth Schedule). 
legislate.$^{34}$ In the matter of public health, it is listed under List III, the Concurrent List in the Ninth Schedule of the Act implying that either state or federal may legislate upon the issue. However, as a matter of fact, health issues involve the most expensive expenses. In order to enforce and protect the public health, either state or federal may legislate. Thus, it should be taken into consideration in certain circumstances where federal has the most authoritative power to legislate. ${ }^{35}$ Therefore, it should be listed under the Federal List matter where federal administration will look into the matter.

Looking into this issue, the fifth Malaysian Prime Minister, Datuk Seri Abdullah Ahmad Badawi did emphasize that Malaysia should always beware and prepare an effective mechanism to protect Malaysian citizens from any biological disaster in the future. He stressed on the issue of infectious diseases which nowadays have ignored geographical and national boundaries. Furthermore, the increase of globalization in the area of biotechnology industry is creating a situation in which a terrorist group could possibly acquire biological agents, equipment or weapons through various approaches includes through the emergence of infectious diseases. ${ }^{36}$ With reference to that, currently, there is no specific legislation in Malaysia to criminalize the person who use or produce biological weapon to cause threat and harm to the public. Thus, if there is a case involving any kind of criminal use and production of biological weapon in Malaysia, no law will specifically govern the offence. It is clear that in criminal aspect, Malaysia has the Penal Code as domestic law to enable the perpetrator of such offences to be prosecuted according to Malaysian criminal law. Unfortunately, there is no provision with regards to the protection of the threats to the public in the events of bioterrorism. No provision is specifically provided for under the Penal Code to protect any act of crimes relating to public health.

34 Andrew Harding, Law, Government and the Constitution in Malaysia, (Kuala Lumpur: Malayan Law Journal, 1996), 168.

35 Rohani Abdul Rahim and Nor Anita Abdulllah "Bioterrorism: Is There Any Legal Protection." (paper presented at the national conference on Law and Technology 2008, Faculty of Laws, Universiti Kebangsaan Malaysia, Palm Garden Hotel, Putrajaya, December, 18-19, 2008).

36 An opening remark by Tun Abdullah Badawi in the International Conference on "Biosafety and Biosecurity Asia 2007." Putra World Trade Center, Kuala Lumpur, Malaysia (21 - 22 May 2007) http://www.pmo.gov.my/ ucapan/?m=p\&p=paklah\&id=3097 (accessed September 10, 2011). 
The Penal Code only concerns about the criminalization of man towards man. When it comes to any offences relating to the use of biological agents as biological weapons, it seems that there is no legal indication to protect man towards the harms cause However, looking at the event of September 11, 2001 at World Trade Center, United States of America, Malaysia has taken serious precautionary measures toward oncoming threat especially when it involves the biological threats which will cause bioterrorism. In fact, the threat of terrorism encountered by the world today affects all nations and so far, it had reached impact not only to the national security, but also to the health stability of the country. Thus, Malaysia reiterates its commitment to fight against terrorism whereby Malaysia strongly believes that efforts should be focused on the prevention and brainpower among law enforcement agencies. Early emphasis on the discovery and efficient efforts to deal with the underlying causes of terrorism should be done as a preparation. As a result, Malaysia had amended the Penal Code in 2003 by enacting terrorism as a criminal offence which has been discussed under Chapter VIA (Section 130B - Section 130T). ${ }^{37}$ The following definitions of a 'terrorist' and 'terrorist act' have been brought in the Penal Code to classify the offences as 'any person who (a) commits, or attempts to commit any terrorist act; or (b) participates in or facilitates the commission of any terrorist act. ${ }^{38}$

Another act which also involves terrorism as a criminal offence is being in possession of corrosive and explosive substance and the carrying of offensive weapons. This is provided for under the Corrosive and Explosive Substance and Offensive Weapons Act 1958. According to the Act, 'offensive weapons' includes any instruments which is used as weapon of offence is likely to cause hurt and 'scheduled weapon' means any offensive weapon specified in the Second Schedule. ${ }^{39}$ Nothing herein mentioned the protection of public in the event of the use of biological agent as a weapon. The provisions are too general. It does not involve any use of biological

37 Edmund Bon Soon Tai, "Impact of Terrorism and Anti-Terrorism Measures in Asia: Malaysia," Malaysian Bar, 2004, p. 2. http://www.malaysianbar.org. my/human_rights/impact_of_terrorism_and_anti_terrorism_measures_in_ asiamalaysia.html (accessed September 25, 2012)

38 See Section 130B (1) of the Penal Code of Malaysia.

39 See Section 2 of the Corrosive and Explosive Substances and Offensive Weapons Act 1958 . 
weapons which can spread the infectious diseases to the public. However, from the introduction of a new Act which is known as the Strategic Trade Act 2010, a definition of 'biological weapon' ${ }^{40}$ has been defined. The term 'biological weapon' currently acts as a new approach in defining and introducing weapon in Malaysia legally. This Act is actually the most recent provision which is introduced to control over the export, transshipment, transit and brokering of strategic items, including arms and related material and other activities which may involve the development and production of weapons of mass destructions in Malaysia. Thus, the legal definition introduced has proven to raise the Malaysian legal awareness and preparedness about the threat of the use of biological agents as biological weapon.

\section{Legal Approach: Managing the Threat of Infectious Diseases}

Prevention and Control of Infectious Disease Act 1988 (PCIDA) is the only Act available in Malaysia governing infectious diseases. The core function of the Act is to be used in the prevention of importation of infectious diseases and the control of the spread of the infectious diseases whenever it occurs either in Malaysia or outside Malaysia. In order to achieve the objective of prevention and control of infectious diseases, collaboration is made between Malaysia and International Health Regulation (IHR) under World Health Organization (WHO) as most of other countries in the world. As to the protection of importation of infectious diseases that might be dangerous to the public health in Malaysia, Part III, states that 'whenever notification is received under the IHR that an infected area exists outside Malaysia, the Minister may by order in the Gazette declare such area to be an infected area for the purpose of the Act' ${ }^{41}$ Thus, whatever notification received under the IHR which affect other countries outside Malaysia will be declared as an infected area in order to prevent the infectious diseases spread into

40 See Section 2 of the Strategic Trade Act 2010, the definition of 'biological weapons' as 'any microbial or other biological agents or toxins whatever their origin or method of production, of types and in quantities that have no justification for prophylactic, protective or other peaceful purpose, and weapons, equipment or means of delivery designed to use biological agents or toxins for hostile purposes or in armed conflict'.

41 See Section 6 of the Prevention and Control of Infectious Disease Act 1988. 
Malaysia. ${ }^{42}$ For example, when H1N1 outbreak attacked Malaysia in 2009, the mode of notification of the outbreak was important. Based on the notification given by the first party who knew about the outbreak (normally doctors and physicians), the authorised authority could take appropriate measures to control the spread. ${ }^{43}$ In fact, PCIDA is seen as a positive method used in controlling the outbreak from spreading. If the infected area occurs in Malaysia, the place will be declared as infected area. These provisions may be regarded as one of the protections given to the public in ensuring the public health safety in the event of any attack of infectious diseases which potentially cause bioterrorism.

PCIDA also provides other alternatives and suggestions in ensuring the diseases which is likely to spread to the public such as to quarantine or isolation as provided under Part IV, which states that 'an authorized officer may cause any person who is infected or whom he has reason to believe to be infected to be removed to a quarantine station for treatment and may detain the person at the station until he can be discharged without danger to the public'. ${ }^{4}$ In that case, any infected person or suspects must be separated from the public in order to avoid any mass infection. Enforcement will be taken into consideration in preventing the infectious diseases from spread to the public at large.

By looking into the legal provisions provided above, a question may arise with regards to the adequacy of such laws itself in protecting public health in the event of biological threats. Therefore, it is true to say that our country in the present time has no such special laws or adequate laws to deal with the immediate problems ${ }^{45}$ of bioterrorism as in the case of biological attacks where it may spread

42 Failure to notify of the H1N1 constitutes an offence under the PCIDA, where upon conviction, the offender is liable in respect of a first offence, to imprisonment for a term not exceeding two years or to a fine or to both; in respect of a second or subsequent offence, to imprisonment not exceeding five years or to a fine or to both; and in respect of a continuing offence, to a further fine not exceeding RM200 for every day during which such offence continues.

43 Nuraisyah Chua Abdullah, "Influenza A H1N1: Strategies and Legal Responsibilities of Hoteliers, Air Carriers, Travel Agents and Tour Operators," Malayan Law Journal Article 5 [MLJ] (2009): lvi, p. 5.

44 See Section 14 of the Prevention and Control of Infectious Disease Act 1988.

45 Harding, n. 35 at 166. 
without anyone realizing and as a consequence, it may cause a major destruction not only to the public health, but to the national security as well.

\section{Findings}

The prior debate about the reality of bioterrorism was highlighted for a long time. It was suggested that the origin of bioterrorism may exist naturally through the emergence of infectious diseases, agents and viruses which are readily available in open sources. Otherwise, it may emerge intentionally through the act of terrorists by misusing the accessibility and availability of the biological agents as weapon. Furthermore, the effects of bioterrorism to spread only can be detected after quite some time. It may take a week before the actual symptoms of bioterrorism can be determined, and to wait until the confirmation by the medical experts. In such circumstances, it is very difficult for the parties involved to take action to deal with the matter from the beginning of the existence of the infectious diseases.

Based on the interviews carried out with the three relevant experts in this area, all of them agreed that the emergence of bioterrorism in Malaysia was undeniable. The fact that Malaysia is having its own experience in facing various types of infectious diseases such as SARS, H1N1, Nipah Virus and others, and the subsistence of these diseases operate as a contributor to the threat of bioterrorism and the most important point is, most of these diseases are animal diseases. In fact, the diseases may occur naturally or by intentional means. The possibility of the emergence of the diseases as an act that will lead to the occurrence of bioterrorism, and it seems to introduce a new dimension of threat today.

Moreover, the statement can also be proven through the existence of a strong partnership and cooperation between Malaysian and international organisation in public health matter such as WHO-IHR, $\mathrm{CDC}$, OIE and FAO. International organisation plays an important role to ensure the protection to the worldwide community. The establishment of TIDREC itself as a research center for a tropical disease also proved that Malaysia is seriously taking the threat of bioterrorism that will possibly incur risks to the public health and national security. Besides that, a discussion towards the possibility 
of the agents misuse has led to the introduction of Malaysian Draft of Biological Weapon and Toxin Convention. Malaysia is not only a dormant member of $\mathrm{BWC}$, but at the same time it is trying to show its commitment to undertake the provisions under BWC.

Biological threats also had raised new concerns about national security throughout the world. Therefore, the question now is whether the Malaysian government is aware about the impending threat likely to be caused by biological agents or weapons. As a result of the Draft of Biological Weapon and Toxin Convention, it has undoubtedly raised Malaysian awareness and concern towards the threats. However, there are a lot of things to be taken into consideration as a matter of preparedness and prevention in the event of bioterrorism. Thus, the issue of introducing a specific law on bioterrorism should be made clear. The main purpose of introducing the law on bioterrorism is to cope with the administrative and legal protection in Malaysian legal approach. It should be designed to meet the critical need in Malaysian security system as well as public health matter in case if bioterrorism threats become a reality. As a turning point, based on the earlier discussion, Malaysia experienced the risk of the threat of terrorism from the event of September 11. The phenomena had widely opened the eyes of the world to always be prepared and respond to the fear of bioterrorism. After the event, the signal is crystal clear as to what degree of disaster it was signaling since it has already occurred in USA. Thus, what Malaysia has learnt since the event is the amendment to the Penal Code in 2003 to include 'terrorism' and 'terrorism-related offences' ${ }^{46}$ and the latest is the existence of Strategic Trade Act 2010 which defines 'biological weapon' ${ }^{47}$ However, according to these two Acts which have actually discussed in part the issue of bioterrorism seem not to be appropriate and thus insufficient to deal with the global threats caused by biological agents or weapons. In fact, the issue of bioterrorism covers a different perspective of public health and national security matters. An effort to deal with the issue has brought greater attention from the beginning especially in enlightening the area of public health and security functions such as infectious diseases surveillance as response to the emergence threats.

46 Chapter VIA (Section 130B-Section 130T) of the Penal Code of Malaysia.

47 See Section 2 of the Strategic Trade Act 2010. 
The scope of the potential impact resulted from the emergence of infectious diseases should be taken into consideration on how it will affect the life of people. There is no doubt that bioterrorism has penetrated an influence relationship between infectious diseases and the scope of public health and security. Clearly, people in the society should get ready to deal with the threats whenever it occurs.

\section{Conclusion}

Although most concerns of bioterrorism focus on the human threat, it may result to a similar threat to livestock or crops. There is a link and inter-relation between human, animals and plants. An important part is the difficulties to differentiate between the natural occurrence and intentional introduction of the infectious diseases. Furthermore, the principle of responding and preventing the infectious diseases would seem to apply to natural occurring these so-called infectious diseases and also the intentional introduction of the diseases. The prospects of having to deal with the biological threats or the occurrence of infectious diseases that will cause bioterrorism are not fiction anymore. Considering what has happened since the event of September, 11, it becomes reasonable and normal to feel anxious about the risk posed by bioterrorism activities as far as issues of public health and security are concerned.

Bioterrorism highlights the challenges in the public health and security functions. In fact, bioterrorism is primarily a federal issue, not a state issue. Thus, any actions taken to prevent and to respond to the threats of bioterrorism should be a federal priority. To act in response, cooperation between public health and security with legal enforcement will operate as a prerequisite solution in bioterrorism planning and response. The public health and security threats caused by bioterrorism requires a well functioning legal enforcement mechanism in place that would play a proactive role in combating as well as responding to any threats of biological attack.

The comprehensive preparedness can only be proven from effective and appropriate mechanisms i.e. availability of specific laws, etc. The Malaysian government as well as the public must play an effective role in the fight against bioterrorism. We have to remember that the suggestion to prevent and respond to bioterrorism activities in 
a Malaysian context somehow presents unique complexities among the public at large i.e. in understanding how serious is the situation if in case we are faced with some threats as a result of bioterrorism. Thus, it is not only a matter to be discussed from a scientific perspective among the scientist's background and professionals. Furthermore, public health issue specifically public health law has always been neglected since centuries ago. The event of bioterrorism would also constitute a grave threat to the function of laws as human legal protection. In that sense, it is the best suggestion to focus on the link between public health and the law to act as major legal protection to the public health at large as well as security concerns.

\section{Bibliography}

Anderson, Burt, Herman Friedman, and Mauro Bendinelli. Microorganisms and Bioterrorism. USA: Springer, 2006.

"A Report on Biosecurity and Biosafety." In International Conference on Biosafety and Biosecurity in Asia 2007, 2007. http://www.pmo.gov.my/ucapan/?m=p\&p=paklah\&id=3097 (accessed 10 September 2011).

'Bio-terrorism', Postnote of Parliamentary Office of Science and Technology, No. 166 (2006): 4.

Dando, Malcolm R., and Kathryn Nixdorff, eds. An Introduction to Biological Weapons.

Edited by Kathryn McLaughlin and Kathryn Nixdorff, Bwpp Biological Weapons Reader. Geneva, 2009.

Duncan, Anabelle. "A History of Biological Weapons Black Death and Yellow Rain." In Mathew R.J, edited by Mathew R.J. Australia: Asia Pacific Centre for Military, Melbourbe University Law School, 2005.

Fidler, P. David. "Globalization, International Law, and Emerging Infectious Diseases." Perspectives of Emerging Infectious Diseases 2, no. 2 (April- June 1996): 77. 
Harding, Andrew. Law, Government and the Constitution in Malaysia. Kuala Lumpur: Malayan Law Journal, 1995.

Hillman, Maurice R. "Overview: Cause and Prevention in BioWarfare and Bioterrorism." Vaccine 20, (2002): 3057.

Katz, Rebecca. "Biological Weapons: A National Security Problems That Requires a Public Health Response." In Working Paper Series. Office of Population Research of Princetown University, 2001-2004.

Kit, Lam Sai. "A Potential Agent for Bioterrorism." Antiviral Research 57, (2003): 113-119.

Nor Anita Abdullah and Rohani Abdul Rahim. "Bioterrorism: New Threats to Health and Security." Paper presented at the international seminar and workshop on Terrorism: Redefining, Preventing and Combating. Universiti Brawijaya, Malang East Java, 2011.

Nuraisyah Chua Abdullah, "Influenza A H1N1: Strategies and Legal Responsibilities of Hoteliers, Air Carriers, Travel Agents and Tour Operators." Malayan Law Journal Article 5 [MLJ] (2009): lvi.

Patton, Micheal Quinn. Qualitative Evaluation and Research Methods. London: Sage Publications, 1990.

Piew, Chua Yan. Kaedah Penyelidikan. Kuala Lumpur Mc Graw Hill Education, 2006.

Rohani Abdul Rahim and Nor Anita Abdullah. "Bioterrorism: Is There Any Legal Protection?" Paper presented at the national conference on Law and Technology, Palm Garden Hotel Putrajaya, November 11-12, 2008.

Rohani Abdul Rahim and Nor Anita Abdullah. "Sars Threats on Public Health in Malaysia: Issues and Challenges." Paper presented at the international conference on Corporate Law, Airlangga Surabaya, June 1-3, 2009. 
Rohana Yusof, Penyelidikan Sains Sosial. Kuala Lumpur: PTS Publication, 2004.

Sazaly Abu Bakar, Director of Tropical Infectious Diseases Research Center and Education (TIDREC) (interviewed on 18 January 2012)

Spence, Scott, and Ralf Trapp, eds. A Brief Comparison on Chemical and Biological Weapons Conventions. Edited by Kathryn McLaughlin and Kathryn Nixdorff, Bwpp Biological Weapons Reader. Geneva, 2009.

Soon, Edmund Bon Tai. "Impact of Terrorism and Anti-Terrorism Measures in Asia: Malaysia." (2004).

Sutton, Victoria. Law and Bioterrrosim. USA: Carolina Academic Press, 2003.

Valderas, Michelle Wright, and R. Martin Roop II, eds. Brucella and Bioterrorism. Edited by Burt Anderson, Herman Friedman and Mauro Bendinelli, Microorganisms and Bioterrorism. USA: Springer, 2006.

Zalini Yunus, Wong Mee Choo, and Devan K. Ramu. "Experiences of Malaysia in Implementing Biological Weapons." In Biological Weapons Convention Regional Workshop, edited by Mathew R.J. Australia: Asia Pacific Centre for Military, Melbourne University Law School, 2005.

Zalini Yunus. "Combating and Reducing the Risk of Biological Threats." The Journal of Defence and Security 1, no. 1 (2010): $1-15$.

Zalini Yunus, Head of Human Factors, Protection and Biophysical Technology Division, Science and Technology Research Institute for Defence (STRIDE), Ministry of Defence (interviewed on 27 December 2011)

Zurin Azlin, Veterinary Officer at Department of Veterinary Service Perak (interviewed on 28 February 2011) 


\section{Statutes}

Convention on the Prohibition of the Development, Production and Stockpiling of Bacteriological (Biological) and Toxin Weapons and on their Destruction 1972

Corrosive and Explosive Substances and Offensive Weapons Act 1958 (Act 357)

Federal Constitution of Malaysia 1957

Penal Code of Malaysia (Act 574)

Prevention and Control of Infectious Diseases Act 1988 (Act 342)

Strategic Trade Act 2010 (Act 708) 